\title{
The Enduring Marginalization of Women's Studies in Academia: A Case Study of Simon Fraser University, 1968-2008
}

\author{
Julia Smith, Simon Fraser University
}

This paper examines the formation of the Women's Studies Department at Simon Fraser University. While the struggle to establish this, the first credit Women's Studies program in Canada, was a significant part of the second wave women's movement and a crucial step towards achieving the broader goal of reinserting women back into academic discourse, in many disciplines the study of women continues to remain peripheral to "traditional" areas of inquiry. This paper will argue that although the establishment of the Women's Studies department was a monumental achievement for women at the time and has undoubtedly greatly improved the status of women's voices within academic research, it is not enough. What is required now is the incorporation of these voices into the mainstream disciplines; the ideal being an academic world that fully reflects the pluralistic society in which we live.

The topic for this paper grew out of my confusion and frustration over the classification and content of courses at my own academic institution, Simon Fraser University (SFU). Having taken numerous history classes, I have repeatedly encountered the same male-centered course structure - the majority of the course is devoted to "mainstream" (male) history while only a lecture or reading is reluctantly sacrificed to "the woman question." My curiosity piqued, a close examination of the university's academic 
calendar revealed that of the History Department's 170 courses, only 1 deal explicitly with women. ${ }^{1}$ When discussing this glaring gender imbalance with my fellow students, I was repeatedly reminded that “those types of courses (women's history courses) are found in the Department of Women's Studies.

Rather than allaying my concerns, the implied suggestion 30| that courses looking at women be restricted to women's studies departments only increased my frustration. Such thinking bolsters what I perceive to be the fundamental problem facing women's studies today: the notion that the academic study of women must always be separate from the "traditional" disciplines. While not discrediting the importance of women's studies as a specialized interdisciplinary department, one must question why the push for academic recognition ended with the formation of women's studies departments. Why have women not become an integral part of the dominant academic discourses? What accounts for the enduring marginalization of women's studies in academia?

A close examination of the formation of women's studies departments sheds some light on the matter. Using the Department of Women's Studies at SFU as a case study, this article explores the challenges and constraints faced by the individuals who struggled to establish women's studies departments in North American universities during the 1970s. Like other academic feminists of this time period, the founders of SFU's Department of Women's Studies set out to "transform the disciplines", however, their initial goal of complete academic

\footnotetext{
1 “Student Services Data Searches," Simon Fraser University Student Services, http://www3.reg.sfu.ca/Tango/course_index/search.taf?function=search\&start= 1 (accessed 22 July 2008).

Past Imperfect 14 [2008) |@ |ISSN 1711--053X| elSSN 1718-4487
} 
transformation was significantly tempered with by the hostile historical circumstances they faced. ${ }^{2}$ Specifically, the belief that women's studies was simply a passing social "fad" combined with an underlying skepticism about the feasibility of women's studies as an academic discipline created an environment inhospitable to such a program. Forced to tailor their design for a women's studies program to an unreceptive university administration, the program was thus designed, proposed, and approved under the assumption that it would only "supplement" the other disciplines. ${ }^{3}$ This article thus argues that the establishment of women's studies programs that were fundamentally extraneous and supplementary to the other disciplines has contributed to the view that the academic study of women must be separate and specialized. The article suggests that scholars and students of women's studies counter this problem by returning to the founders' original goal of transforming the academic disciplines.

Like other women's studies departments, the establishment of SFU's Department of Women's Studies was strongly linked to the Women's Liberation Movement. Although the origins of the Women's Liberation Movement must not be attributed to any one person or group, the experiences of female activists in the student organizations of the New Left contributed greatly to the emergence of a "second wave" women's movement in the $1960 \mathrm{~s}^{4}$ Increasingly aware of the gender inequality that

\footnotetext{
${ }^{2}$ Elizabeth L. MacNabb, et al (Eds) Transforming the Disciplines: A Women's Studies Primer (New York: Haworth Press, 2001).

${ }^{3}$ Simon Fraser University (SFU) Archives, Collections File, Women's Studies Department, "Women's Studies at Simon Fraser University” (report), 1984,1 .

${ }^{4}$ Comprised mostly of student and intellectual radicals, the New Left differed substantially from previous left movements in that it focused largely on 
permeated the New Left, female student activists began to question women's role within both the movement and society. When their male counterparts reacted with hostility and derision, some of these women decided to form independent women's groups or caucuses. Within these groups women engaged in consciousness-raising, a newly devised form of feminist organizing 32| whereby small groups of women met to discuss issues of importance to them. ${ }^{5}$

The SFU Women's Caucus was formed in late 1968. Shortly after the well-known student occupation of the Board of Governors' room in June 1968, a few of the women involved in the student activist organization, Students for a Democratic University, began to voice concerns that their needs were not being adequately addressed within this male-dominated group. ${ }^{6}$ Moreover, they felt that their work was not being recognized as "exactly equal to what the guys were doing.", In response, the first meeting of the Feminist Action League was organized for July. The university community met this event with much concern and derogation, as is evidenced by the fact that the doors

intellectual and social currents instead of the usual Marxist" issues of class and labour. For more on the New Left see Dimitrios Roussopoulos (Ed) The New Left: Legacy and Continuity (Montreal: Black Rose Books, 2007).

${ }^{5}$ Nancy Adamson et al Feminist Organizing for Change: The Contemporary Women's Movement in Canada (Toronto: Oxford University Press, 1988), 44. Although many of the initial caucuses were formed on university campuses, many quickly moved off-campus in an effort to reach more women.

${ }^{6}$ In early June forty students occupied the SFU Board of Governors' room for five days and six nights, to protest the university's refusal to award course credit to students who had taken transfer courses at local colleges. For more on the occupation see Hugh Johnston, Radical Campus: Making Simon Fraser University (Vancouver, Toronto: Douglas \& McIntyre, 2005).

${ }^{7}$ Marcy Toms, quoted in Francis Jane Wasserlein, “'An Arrow Aimed at the Heart': The Vancouver Women's Caucus and the Abortion Campaign, 19691971" (MA thesis, SFU, 1990), 57.

$$
\begin{gathered}
\text { Past Imperfect } \\
14 \text { [2008) | (C) |ISSN 1711-053X | elSSN 1718-4487 }
\end{gathered}
$$


to this first "women-only" meeting had to be locked in order to keep out prying male eyes. ${ }^{8}$ The Peak, SFU's student newspaper, also ran an article covering the meeting under the headline, "Pussy Power Strikes at SFU." In response to this offensive headline, members of the Feminist Action League sent in an article detailing who they were and what they hoped to achieve, subsequently published under the headline "Pussy Power Strikes Back."

Two months after this initial meeting, in September 1968, the Women's Caucus was formed. Made up of students, staff, and faculty, this new group represented "a convergence of several inter-related groups of women who had become concerned with their place in the student political organizations, as well as in the world at large."11 Any doubts surrounding the need for an organization promoting women's issues were washed away in October 1968, when, after placing a small ad in The Peak providing a contact number for women seeking help and advice, the Women's Caucus Counselor was inundated with phone calls from across Western Canada. ${ }^{12}$ While the group was active in university affairs, the growing political turmoil at SFU made it difficult to maintain their focus on women's issues. ${ }^{13}$ In addition,

\footnotetext{
${ }^{8}$ Francis Jane Wasserlein, "An Arrow Aimed at the Heart,"57.

9 "Pussy Power Strikes at SFU," The Peak, 3 July 1968.

10 "Pussy Power Strikes Back," The Peak, 10 July 1968.

${ }^{11}$ Francis Jane Wasserlein, "An Arrow Aimed at the Heart," 56.

${ }^{12}$ The Peak, 9 October 1968; Margaret Benston quoted in Francis Jane Wasserlein, "An Arrow Aimed at the Heart," 60.

${ }^{13} 1968$ and 1969 saw several significant events transpire at SFU. Most notable among these were another occupation of the Board of Governors' room in November 1968, and the strike by students and faculty of the Politics, Sociology \& Anthropology Department in Fall 1969. For more on the political turmoil at SFU during this time period see Johnston, Radical Campus. 
many of the members wished to expand their focus to the broader community of non-university women. ${ }^{14}$ This being the case, it was soon decided that substantial change could not be effected within the confines of Burnaby Mountain. As such, the Women's Caucus moved off the mountain in June 1969.

Despite the relocation of the Women's Caucus, the 34 members at SFU remained active on campus. They continued to lobby for the dissemination of information and resources on a number of women's issues, such as birth control and childcare, and to voice their concerns to the university administration and student body. Heavily influenced by broader North American trend of increasing interest in feminist theory and research on women, members of the SFU Women's Caucus began to encourage research that would add to "information [about] and analysis of the social situation of women and its historical development." 15 As such, members of the SFU Women's Caucus, along with a number of other students and faculty interested in establishing a women's studies program, began lobbying for the creation of courses that examined women. A result of their efforts, over the next few years SFU offered a number of credit and non-credit courses with women as the focus. For example, in Fall 1971 the university offered its first course looking at women, Geography 404: The Geography of Gender. Team-taught by a number of female faculty members involved in both the Women's Caucus

\footnotetext{
${ }^{14}$ Wasserlein, "An Arrow Aimed at the Heart," 56.

${ }^{15}$ Marcy Cohen and Jean Rands as quoted in Wasserlein, "An Arrow Aimed at the Heart," 66. For more on the increasing interest in feminist theory and research in Canada during this time period see Minds of Our Own: Inventing Feminist Scholarship and Women's Studies in Canada and Quebec, 19661976, eds. Wendy Robbins et al. (Waterloo, ON: Wilfrid Laurier University Press, 2008).

Past Imperfect 14 [2008] | (C) |ISSN 1711-053X | eISSN 1718-4487
} 
and the design of women's studies at SFU, the aim of the course was to provide students with "a geographic overview of the role of gender as a fundamental determinant of cultural activity." ${ }^{16}$ In Spring 1973, SFU offered a further series of on-campus non-credit courses while the university's continuing education program provided a number of others. Perhaps the most important of these early courses was the series of non-credit SFU seminars held at Burnaby's McGill Library in 1972 that gave an overview of the Women's Liberation Movement. With an enrolment exceeding original estimates by fifty per cent, organizers were shocked as people from both SFU's student population and Burnaby's private citizenry signed up in significant numbers. ${ }^{17}$

Motivated by the enthusiastic response to these preliminary courses and determined to see the official establishment of women's studies at SFU, various groups began the challenging task of developing a women's studies program. In an effort to garner student support, the Ad Hoc Student Committee for a Women's Studies Program at SFU (AHC) was formed in early 1974. With a primary objective of "focus[ing] awareness among the student body of the need for a Women's Studies Program," the group held meetings, organized information sessions, and published numerous articles in The Peak. ${ }^{18}$ Concurrently, some of the same faculty who would soon form the women's studies drafting committee decided that the time had come to draft a women's studies proposal. The issue facing these

\footnotetext{
${ }^{16}$ GEOG 404 Course Outline cited in SFU Archives, "Women Studies," 2.

${ }^{17}$ SFU Archives, "Women Studies," 2.

18 "Women's Studies Committee being formed at SFU," The Peak, 20 March 1974. A perusal of The Peak from March 1974 to July 1975, the year leading up to the establishment of the women's studies program, reveals countless articles on the need for women's studies at SFU.
}

$$
\begin{gathered}
\text { Past Imperfect } \\
14 \text { [2008] | () |ISSN 1711-053X | elSSN 1718-4487 }
\end{gathered}
$$


women now was how to structure their proposal so as to achieve their goal of inserting women into academic discourse without being subsumed by the other disciplines.

At the time, and continuing through to today, the debate on the structure of women's studies programs centers on two major schools of thought within women's studies: integration 36| versus autonomy. Integrationists argue that women's studies should focus on convincing the "The Powers That Be" to include women in the curriculum. They believe that through acts of convincing, informing, and consciousness-raising, the malefocused education system can be transformed. In contrast, autonomists purport that women's studies is a field of academic study in its own right. They maintain that change can only be brought about by "radical, innovative feminist scholarship that is given a chance to grow in a setting where there is vibrant exchange and debate among autonomous feminist scholars who have control over their knowledge-making." "19 Although most proponents of women's studies programs advocate a combination of the two approaches, this can lead women's studies to suffer significant setbacks. Relegated to the margins of academic study with little or no effort made to incorporate the important work of women's studies into the traditional disciplines, the result of this "ghettoization" is often some variation of the situation at SFU: courses on women are, for the most part, limited to the Department of Women's Studies. As such, instructors within the traditional disciplines are obliged to make only brief mention of

\footnotetext{
${ }^{19}$ Gloria Bowles and Renate Duelli Klein, "Introduction: Theories of Women's Studies and the Autonomy/Integration Debate," in Gloria Bowles et al (Eds) Theories of Women's Studies, (London: Routledge \& Kegan Paul Inc., 1983), 2.

Past Imperfect

14 [2008] | (C) |ISSN 1711-053X| eISSN 1718-4487
} 
women within their courses, and thus alleviated from allocating significant time or resources to the matter. The lack of attention paid to women is then justified with the assertion that courses examining women are covered by women's studies. Ultimately, this pattern only serves to reinforce and perpetuate the problematic notion that the study of women must be separate and specialized and that such terms as "normal," "traditional," and "mainstream" mean "male."

In spite of the possibility of academic ghettoization, the women's studies drafting committee at SFU opted for a combination of the autonomy/integration approaches. The result of this decision was the proposal of a women's studies program with the fundamental purpose of supplementing and correcting the other disciplines. Completed in July 1974, the proposal was written by ten influential women: Margaret Benston, Cindy Cole (Kilgore), Sara David, Wendy Eliot-Hurst, Jamila Ismail, Dana Janssen, Andrea Lebowitz, Honoree Newcombe, Bertie Rush, and Marilyn Webb. In keeping with the notion of courses designed only to supplement and correct, the drafting committee decided to pursue a minor program for a number of reasons. Firstly, a minor would be more financially feasible, as minors are significantly cheaper to implement and maintain. More importantly, it was believed that a minor would enhance the inherent interdisciplinary nature of women's studies, as students would then carry their knowledge of women over to their major disciplines. $^{20}$

In the months following the completion of the proposal, the drafting committee had to guide it through the necessary

\footnotetext{
${ }^{20}$ SFU Archives, “W omen Studies," 1. 
bureaucratic channels. After being approved in principle by the Academic Planning Committee on 13 November 1974, the proposal was presented to the Senate Committee on Undergraduate Studies (SCUS) on 22 April 1975. It was here that the women behind the proposal met with their first substantial opposition. Although the proposal was approved by a vote of 38| nine to one, many questions were raised by the university administration about both the motivations behind women's studies and its academic viability.

These issues were fundamentally centered on the notion of women's studies as merely a temporary social movement rather than a legitimate academic discipline. Firstly, concerns were raised over whether or not there was enough student interest to even merit the creation of a women's studies program. Secondly, doubt was expressed as to the amount of resources available to teach such a program should it be approved. A still relatively new academic field, at issue was a lack of scholars as well as scholarly material with which to teach. Thirdly, the issue of academic feasibility was seen as a major problem. Those opposed to a women's studies program maintained that women's studies was nothing more than a social movement, therefore negating any possibility of developing it into a systematic and scholarly study. Lastly, it was recommended, most vehemently by Klaus Rieckhoff (then Associate Dean of Graduate Studies) that the program be broadened to include human prejudices in general, rather than restricted only to women. ${ }^{21}$ Over the next few months the same issues initially voiced at this SCUS meeting, were

\footnotetext{
${ }^{21}$ Simon Fraser University Office of the Senate Secretariat, Senate Committee on Undergraduate Studies Minutes, R.C. Brown to B.G. Wilson, 25 April 1975.

Past Imperfect 14 [2008) | (C) |ISSN 1711-053X| elSSN 1718-4487
} 
repeatedly raised by other members of the university administration.

The drafting committee set out to systematically refute each and every one of these objections. To counter doubts about student interest, the AHC conducted a survey of 209 students, revealing that $93 \%$ showed a significant interest in taking a women's studies course. ${ }^{22}$ In regards to resources, a report from then Librarian of the Social Sciences Division, Eve Szabo, outlined the growing number of academic publications on the topic of women's studies. ${ }^{23}$ As for academic viability, the committee assembled a comprehensive report on the numerous academic women's studies programs already in existence across North America. ${ }^{24}$ Finally, in response to Rieckhoff's suggestion of broadening the program to include other groups facing prejudice, the committee prepared to argue that the separate study of women only was fundamental to the notion of women's studies. By including other such mixed-gender groups as racial minorities and people with physical disabilities, the program would fail to address the sole issue of women's oppression as women. The drafting committee maintained that as the history of women was different than that of men, regardless of other such influencing factors as race or physical disability, a specialized women-only

${ }^{22}$ Simon Fraser University (SFU) Archives, Women's Studies fonds, F-164-04, "Proposal for a Women's Studies Program at SFU," Appendix A, July 1975.

${ }^{23}$ Simon Fraser University Office of the Senate Secretariat, Senate Committee on Undergraduate Studies Minutes, Minutes of meeting, 7 July 1975.

${ }^{24}$ SFU Archives, "Proposal," Appendix A. For example, in the United States, the first women's studies program was established in 1970 at the San Diego State University, and by 1976 this number had risen to over 270. Mari Jo Buhle, "Introduction," in The Politics of Women's Studies: Testimony from Thirty Founding Mothers, ed. Florence Howe (New York: The Feminist Press at The City University of New York, 2000), xv.

$$
\begin{gathered}
\text { Past Imperfect } \\
14 \text { [2008) | } \odot \text { |ISSN 1711-053X | elSSN 1718-4487 }
\end{gathered}
$$


program was required if the male-centered disciplines were to be adequately corrected and supplemented.

After being sent back to the Academic Planning Committee for further consideration, the proposal finally made its way back to the SCUS for final approval on 7 July 1975 in an evening of intense discussion. As drafting committee member 40| Andrea Lebowitz remembers, the heated debate inside Senate Chambers "came close to the intensity of the electrical storm outside." 25 Again Senate members raised the same core issues, with Rieckhoff speaking at length in general opposition to the proposal; however, this time, the drafting committee was armed with an abundance of research with which to defend the proposal. Consequently, the result was a majority vote in favour of a women's studies program at SFU. Although having begun their efforts only a few years earlier, by July 1975 the members of the AHC had successfully established a women's studies program at SFU. In January 1976 Anita Fellman taught the first women's studies minor course to an inaugural class of forty students. Women's Studies 100: Introduction to Women's Studies provided "an interdisciplinary study of the development of female roles...in Europe and North America from 1800 to the present." ${ }^{26}$ While the fact that this was one of the first credit women's studies programs in Canada is remarkable on its own, it is even more amazing when considering that, having only been established in 1965, SFU was one of the youngest universities in Canada.

\footnotetext{
${ }^{25}$ Andrea Lebowitz quoted in Barbara Diggins and Mary Lynn Stewart, $20^{\text {th }}$ Anniversary, 1975-1995, Women's Studies, Simon Fraser University (Burnaby, Women's Studies Department, Simon Fraser University, 1995), 5.

${ }^{26}$ Women's Studies 100 Course Outline as cited in SFU Archives, “W omen's Studies," 9.

Past Imperfect 14 [2008) | ( ) |ISSN 1711-053X | elSSN 1718-4487
} 
This article has used the establishment of the SFU Department of Women's Studies as a case study through which to examine the struggles of women to set up women's studies programs in North America. It has argued that the enduring marginalization of women in academia can be understood as a result of the particular historical circumstances experienced by the founders of women's studies programs. Specifically, faced with an unreceptive and doubtful university administration, the creators of the SFU Department of Women's Studies proposed a program that was fundamentally extraneous and supplemental in nature; a problem that persists to the present day. True, most women's studies departments have expanded far beyond their initially narrow goal of a minor program that would supplement and correct the other disciplines, in the process achieving a great deal. In regards to SFU, throughout the 1980 s there were many significant developments for the Department of Women's Studies, including the inception of an MA program and the introduction of the Ruth Wynn Woodward Chair. Continuing into the $1990 \mathrm{~s}$, the department saw the introduction of a certificate program in 1990, the offering of joint majors, with English in 1991 and Psychology in 1992, and perhaps the most significant event of the 1990s, the Senate's approval of women's studies as a major.

That women's studies departments now offer a vast array of undergraduate courses and programs, as well as M.A. and $\mathrm{PhD}$ programs, refutes any claims of women's studies as merely a passing fad. In addition, that the faculty and students of women's studies departments have repeatedly been acknowledged for their countless academic achievements dismisses any doubts about the

\footnotetext{
Past Imperfect

14 [2008) | @ |ISSN 1711-053X| elSSN 1718-4487
} 
viability of women's studies as an academic discipline. ${ }^{27}$ Yet despite these achievements, women's studies as a contemporary academic discipline still faces many challenges, one of the most fundamental being that many disciplines have still not fully incorporated the study of women. It is this problem that lies at the heart of my frustration as a female history student interested 42| in studying my past, not only as a citizen, worker, or Caucasian, but also as a woman.

In considering possible solutions, it is important to remember that one of women's studies founding aims was social transformation; a goal that some women's studies scholars have tried to distance themselves from. For example, reflecting on the state of women's studies at the beginning of the twenty-first century, scholars Ann Braithwaite, Susan Heald, Susanne Luhmann, and Sharon Rosenberg state:

In the wake of the political events in the latter part of the twentieth century, what we might possibly share is a sense that any project whose objective is transformation, emancipation, liberation and progress is a lot more difficult to envision than even fifty years ago....Rather than a frame within which we find an easy comfort, direction and purpose for contemporary Women's Studies, our focus...is on that frame as a matter of trouble and to trouble. ${ }^{28}$

\footnotetext{
${ }^{27}$ Faculty and students in the SFU Department of Women's Studies have won many awards, including numerous SFU Excellence in Teaching Awards, the SFU Dean's Medal for best graduate thesis, the Distinguished Masters Thesis Award of the Western Association of Graduate Schools, and Canada's highest teaching award, the $3 \mathrm{M}$ Fellowship.

${ }^{28}$ Ann Braithwaite "Introduction," in Ann Braithwaite et al (Eds) Troubling Women's Studies: Pasts, Presents, and Possibilities (Toronto: Sumach Press, 2004), 31-32.
}

$$
\begin{gathered}
\text { Past Imperfect } \\
14 \text { [2008] | ( ) |ISSN 1711-053X | elSSN 1718-4487 }
\end{gathered}
$$


In short, the present-day emphasis on difference and divergence has led women's studies away from the original goal of transforming the academic disciplines. As such, one possible solution to the enduring marginalization of women's studies in academia is to return to the discipline's original goal of social transformation and redouble efforts to insert women into the dominant discourse of the traditional disciplines. Although it is imperative that women's studies continues to exist as a separate academic discipline, women's studies mandate to "place women at the centre of inter-disciplinary teaching and research about power relations, and to foster knowledge to transform these relations to the benefit of women" must be broadened to include the incorporation of the study of women into the mainstream academic disciplines; the ideal being an academic world that fully reflects the pluralistic society in which we live. ${ }^{29}$

Works Cited

Adamson, Nancy, et al. Feminist Organizing for Change: The Contemporary Women's Movement in Canada. Toronto: Oxford University Press, 1988.

Bowles, G. and R. Duelli Klein. "Introduction: Theories of Women's Studies and the

Autonomy/Integration Debate", In Gloria Bowles et al (Eds) Theories of Women's Studies, London: Routledge \& Kegan Paul Inc., 1983.

Braithwaite, Ann et al. Troubling Women's Studies: Pasts, Presents, and Possibilities, Toronto: Sumach Press, 2004.

Buhle, Mari Jo. "Introduction", in Florence Howe (Ed) The Politics of Women's Studies: Testimony from Thirty Founding Mothers, New York: The Feminist Press at

29 "Mission Statement," Simon Fraser University Department of Women's Studies, 22 July $2008<$ http://www.sfu.ca/womens-studies>

$$
\begin{gathered}
\text { Past Imperfect } \\
14 \text { [2008] | ( ) |ISSN 1711-053X | elSSN 1718-4487 }
\end{gathered}
$$


The City University of New York, 2000.

Diggins, B. and M.L. Stewart. 20 th Anniversary, 1975-1995, Women's Studies, Simon

Fraser University. Burnaby: Women's Studies Department, Simon Fraser University, 1995.

Johnston, Hugh. Radical Campus: Making Simon Fraser University Vancouver, Toronto: Douglas \& McIntyre, 2005.

$44 \mid$

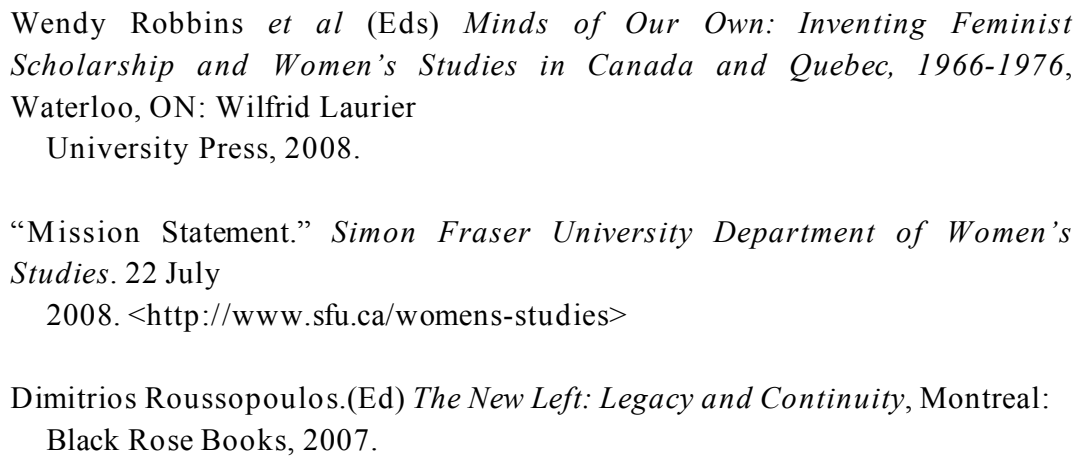

The Peak, July 1968-July 1975.

"Student Services Data Searches." Simon Fraser University Student Services. July 2008 .

$<$ http://www3.reg.sfu.ca/Tango/course_index/search.taf?function=search\&start $=1>$

Simon Fraser University Archives. Collections File, Women's Studies Department.

“Women’s Studies at Simon Fraser University," (report). 1984.

Simon Fraser University Archives. Women's Studies fonds, F-164-0-4. "Proposal for a

Women's Studies Program at SFU,” Appendix A. July 1975.

Simon Fraser University Office of the Senate Secretariat. Senate Committee on Undergraduate Studies Minutes. Minutes of meeting. 7 July 1975.

Simon Fraser University Office of the Senate Secretariat. Senate Committee on Undergraduate Studies Minutes. R.C. Brown to B.G. Wilson. 25 April 1975.

\author{
Past Imperfect \\ 14 [2008) | (C) |ISSN 1711-053X| elSSN 1718-4487
}


Elizabeth L. MacNabb et al (Ed) Transforming the Disciplines: A Women's Studies Primer, New York: Haworth Press, 2001.

Wasserlein, Francis Jane. "'An Arrow Aimed at the Heart': The Vancouver Women's

Caucus and the Abortion Campaign, 1969-1971." MA thesis, Simon Fraser University, 1990. 